\title{
Chitosan against cutaneous pathogens
}

\author{
Jackson Champer ${ }^{1,2^{*}}$, Julie Patel ${ }^{1}$, Nathalie Fernando ${ }^{1}$, Elaheh Salehi ${ }^{1}$, Victoria Wong ${ }^{1}$ and Jenny Kim ${ }^{1,3}$
}

\begin{abstract}
Propionibacterium acnes and Staphylococcus aureus are cutaneous pathogens that have become increasingly resistant to antibiotics. We sought to determine if chitosan, a polymer of deacetylated chitin, could be used as a potential treatment against these bacteria. We found that higher molecular weight chitosan had superior antimicrobial properties compared to lower molecular weights, and that this activity occurred in a pH dependent manner. Electron and fluorescence microscopy revealed that chitosan forms aggregates and binds to the surface of bacteria, causing shrinkage of the bacterial membrane from the cell wall. Of special relevance, clinical isolates of $P$. acnes were vulnerable to chitosan, which could be combined with benzoyl peroxide for additive antibacterial effect. Chitosan also demonstrated significantly less cytotoxicity to monocytes than benzoyl peroxide. Overall, chitosan demonstrates many promising qualities for treatment of cutaneous pathogens.
\end{abstract}

Keywords: Chitosan; Benzoyl peroxide; Acne vulgaris; Propionibacterium acnes; Staphylococcus aureus; Antibacterial

\section{Introduction}

Chitosan is derived from the partial deacetylation of chitin, a natural polysaccharide composed of $\beta 1 \rightarrow 4$ linked $\mathrm{N}$-acetylglucosamine. It has demonstrated potential as a vehicle for drug and DNA delivery via nanoparticles (Singla and Chawla 2001), as a food preserving agent (No et al 2007), and as a wound dressing for severely hemorrhaging injuries (Brown et al. 2009). Chitosan is also known to have antimicrobial activity against viruses (Kurita 2006), fungi, and bacteria (Rabea et al. 2003), which combined with its high biocompatibility, low toxicity, and ability to biodegrade, make it a promising candidate for medical use against various pathogens (Kong et al. 2010). Chitosan has already been shown to be effective in vivo against bacteria (Lee et al. 2009; Moon et al. 2007).

Two common cutaneous pathogens, Propionibacterium acnes and Staphylococcus aureus, have increasingly developed resistance to frontline antibiotics (Song et al. 2011; Patel et al. 2010; Jappe et al. 2008), necessitating the development of alternative treatments. Benzoyl peroxide is a common treatment for acne vulgaris, but it is highly toxic to human cells, making it less than ideal

\footnotetext{
* Correspondence: jtchamper@yahoo.com

${ }^{1}$ Division of Dermatology, David Geffen School of Medicine at UCLA, Los Angeles, CA 90095, USA

${ }^{2}$ Division of Immunology, Beckman Research Institute, City of Hope National Medical Center, 1500 E. Duarte Road, Duarte, CA 91010, USA

Full list of author information is available at the end of the article
}

(Kraft and Freiman 2011). In addition, benzoyl peroxide is very irritating, resulting in poor patient compliance. Topical retinoids are also irritating, and oral isotretinoin, while extremely effective for severe acne, has significant adverse effects, with restrictions on its use implemented by the FDA. Therefore, there is a need to develop novel therapeutics that can effectively treat infectious dermatological diseases without harmful side effects.

Thus, we sought to determine if chitosan has the potential to act as an effective antibacterial agent against $S$. aureus and $P$. acnes, with a focus on treatment of the latter, which has been identified as a factor in the pathogenesis of acne vulgaris (Bellew et al. 2011; Kurokawa et al. 2009). Additionally, we sought to determine the parameters to optimize chitosan's antibacterial properties and investigated the antibacterial mechanism of chitosan, which is not fully understood.

\section{Methods \\ Materials}

Chitosan with $75 \%+$ deacetylation and varying molecular weight was obtained from Aldrich. Chitosan was added at $1 \mathrm{mg} / \mathrm{mL}$ to $0.01 \mathrm{~N}$ aqueous $\mathrm{HCl}$, allowed to dissolve, and then adjusted with $\mathrm{NaOH}$ to $\mathrm{pH}$ 6. Unless otherwise specified, experiments were performed with high molecular weight chitosan (310-375+ kDa).

\section{实 Springer}


Benzoyl peroxide was obtained from Sigma and dissolved in DMSO at $10 \mathrm{mg} / \mathrm{mL}$, immediately diluted to appropriate concentrations, and added to treatments. Final DMSO concentration was 1\%, a concentration found not to affect results.

8 strains of $P$. acnes clinical isolates were obtained from the faces of human volunteers using the tape-strip method, a protocol approved by the Institutional Review Board at UCLA.

\section{$P$. acnes colony-forming unit assay}

P. acnes American Type Cell Culture (ATCC) strain 6919 were grown anaerobically at $37^{\circ} \mathrm{C}$ in Reinforced Clostridial Media (Oxoid) for 3 days and collected in the exponential phase of growth by centrifugation. Bacteria were washed with $\mathrm{pH} 6$ sodium phosphate buffer supplemented with $0.03 \%$ Trypticase Soy Media and quantified by reading with a spectrophotometer at $600 \mathrm{~nm}$ and applying a conversion of $\sim 10^{8} \mathrm{CFU}=1 \mathrm{ab}-$ sorbance unit. Bacteria were then added to treatments at $10^{7} \mathrm{CFU} / \mathrm{mL}$ in a volume of $400 \mu \mathrm{L}$ and incubated aerobically at $37^{\circ} \mathrm{C}$ for 3 hours. Control samples were untreated, and the aerobic incubation was found to have no effect on bacteria viability. Dilutions were conducted, and each sample was plated on brucella agar with $5 \%$ sheep blood supplemented with hemin and vitamin K (Remel). Plates were incubated anaerobically at $37^{\circ} \mathrm{C}$ for 3 days, allowing visible $P$. acnes colonies to form, and colonies were counted to determine concentration before plating.

\section{S. aureus colony-forming unit assay}

S. aureus strain $\mathrm{SH} 1000$ were grown overnight at $37^{\circ} \mathrm{C}$ in Trypticase Soy Broth (Becton-Dickinson), then diluted 1:50 into fresh media, and collected 3 hours later in the exponential phase of growth by centrifugation. Bacteria were washed with $\mathrm{pH} 6$ sodium phosphate buffer supplemented with $0.03 \%$ Trypticase Soy Media and quantified by reading with a spectrophotometer at $600 \mathrm{~nm}$ and applying a conversion of $\sim 5 \times 10^{8} \mathrm{CFU}=1$ absorbance unit. Bacteria were then added to treatments at $10^{7} \mathrm{CFU} / \mathrm{mL}$ in a volume of $400 \mu \mathrm{L}$ and incubated aerobically at $37^{\circ} \mathrm{C}$ for 3 hours. Control samples were untreated. Dilutions were conducted, and each sample was plated on Trypticase Soy Agar. Plates were incubated at $37^{\circ} \mathrm{C}$ overnight, allowing visible S. aureus colonies to form, and colonies were counted to determine concentration before plating.

\section{Electron microscopy}

$P$. acnes were grown as described above, but treatments contained $1 \mathrm{~mL}$ volume with $250 \mu \mathrm{g} / \mathrm{mL}$ chitosan at a concentration of $10^{8}$ bacteria/mL. Bacteria were incubated aerobically for one hour at $37^{\circ} \mathrm{C}$, washed $3 \mathrm{x}$ with $\mathrm{PBS}$ solution, and resuspended in PBS with $2 \%$ glutaraldehyde.
The samples were fixed with $0.05 \%$ osmium tetroxide for 5 minutes, dehydrated in graded ethanol, and embedded in Eponate 12 (Ted Pella). 60-70 nm sections were cut on a Reichert-Jung Ultracut E ultramicrotome and picked up on formvar coated copper grids. The sections were stained with uranyl acetate and Reynolds lead citrate, and examined on a JEOL 100CX electron microscope at $80 \mathrm{kV}$.

\section{Fluorescence microscopy}

Chitosan was labelled with FITC as conducted previously (Qaqish and Amiji 1999). Chitosan was dissolved at $5 \mathrm{mg} / \mathrm{mL}$ in $0.1 \mathrm{M}$ acetic acid. An equal volume of methanol with $0.25 \mathrm{mg} / \mathrm{mL}$ FITC was slowly added while stirring. The solution was kept in the dark for one hour, and then chitosan was precipitated with $\mathrm{NaOH}$. The chitosan pellet was collected by centrifugation, washed $3 \mathrm{x}$ with water, dissolved at $1 \mathrm{mg} / \mathrm{mL}$ in $0.01 \mathrm{~N}$ $\mathrm{HCl}$, and adjusted with $\mathrm{NaOH}$ to $\mathrm{pH}$ 6. P. acnes was grown and washed as described above, except that $100 \mu \mathrm{L}$ of $50 \mathrm{mM}$ CTC solution was added to $3 \mathrm{~mL}$ bacteria cultures before harvesting. $100 \mu \mathrm{g} / \mathrm{mL}$ FITClabeled chitosan was added to $\sim 10^{7}$ bacteria $/ \mathrm{mL}$, and viewed one hour later with a Leica Microsystems TCSSP2-AOBS Confocal Microscope. An argon $488 \mathrm{~nm}$ laser was used for excitation. Green FITC was viewed through a 500-535 nm wavelength filter, and red CTC was viewed through a 599-700 nm wavelength filter.

\section{MTS assay}

Blood was drawn from healthy human volunteers according to a protocol approved by the Institutional Review Board at UCLA. PBMCs were isolated by FicollPaque (Pharmacia) gradient and allowed to adhere for 2 hours in RPMI media with 1\% Fetal Calf Serum (Omega Scientific) in 96-well plates. Cells were washed 3x with RPMI media to obtain adherent monocytes. The $\mathrm{HaCaT}$ cell line of keratinocytes were cultured. Cells of both types were incubated at $37^{\circ} \mathrm{C}$ with treatment in $100 \mu \mathrm{L}$ RPMI media with 10\% Fetal Calf Serum (monocytes) or $\mathrm{HaCaT}$ media (keratinocytes) for 16 hours. $20 \mu \mathrm{L}$ MTS assay reagent (Promega) was added to each well, and cells were allowed to incubate for 4 hours at $37^{\circ} \mathrm{C}$. The absorbance of each well was read at $490 \mathrm{~nm}$, with absorbance proportional to the number of viable cells (Cory et al. 1991).

\section{Results}

\section{Chitosan demonstrates antimicrobial effect against $P$. acnes and S. aureus}

Chitosan demonstrated a concentration-dependent antimicrobial activity against both $P$. acnes and $S$. aureus (Figure 1). Chitosan at $5 \mu \mathrm{g} / \mathrm{mL}$ inhibited $P$. acnes growth by 2 logs and at $10 \mu \mathrm{g} / \mathrm{mL}$ by close to 3 logs. At these lower concentrations, chitosan was more effective at inhibiting $P$. acnes growth than $S$. aureus, which was 


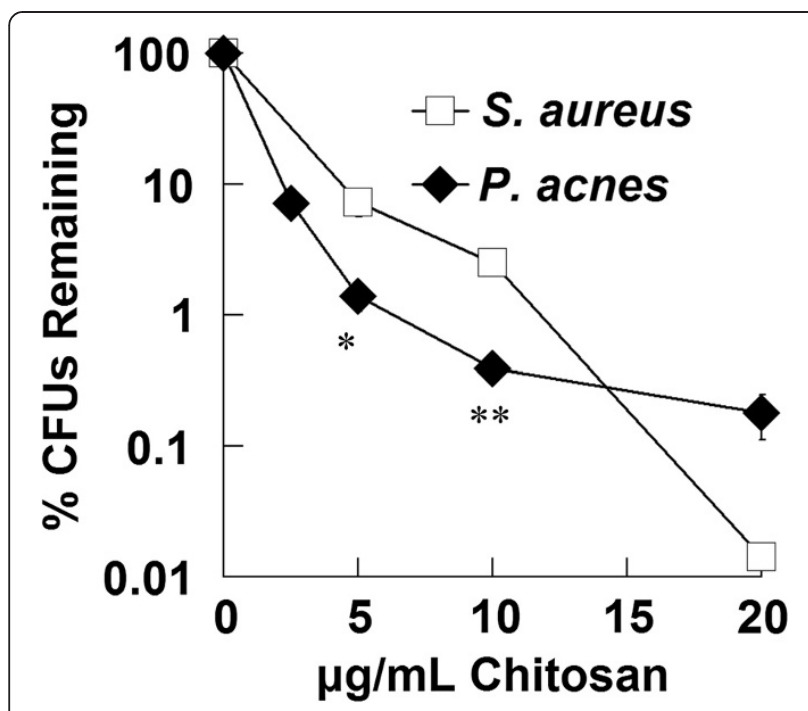

Figure 1 Chitosan demonstrates antimicrobial effect against $P$. acnes and S. aureus. Chitosan was incubated with bacteria for 3 hours to assess antibacterial activity. Bacteria was then enumerated by colony-forming unit assay to determine concentration, which was plotted as a percentage of untreated sample. Error bars represent SEM ( $n=4$, independent experiments). ${ }^{*} p<0.05$ and ${ }^{* *} p<0.01$ (t-test) inhibited by $1 \log$ at $5 \mu \mathrm{g} / \mathrm{ml}$ and by $2 \operatorname{logs}$ at $10 \mu \mathrm{g} / \mathrm{mL}$. At a higher concentration of chitosan $(20 \mu \mathrm{g} / \mathrm{mL})$, chitosan was effective at inhibiting $S$. aureus growth with virtually no $S$. aureus remaining. This may be because $S$. aureus remained in exponential growth throughout the experiment, while $P$. acnes, an anaerobic species, began to shift to a static phase. It has been shown chitosan is most effective against bacteria in the exponential phase of growth (Chen et al. 2002).

\section{High molecular weight chitosan has greater antibacterial activity}

To determine the effect of molecular weight $(\mathrm{MW})$ on antibacterial activity, chitosan of low MW (50-190 kDa), medium MW (190-310 kDa), and high MW (310-375+ $\mathrm{kDa}$ ) were tested. Concentrations of $2.5,5,10$, and 20 $\mu \mathrm{g} / \mathrm{mL}$ were tested against $P$. acnes and 5,10 , and 20 $\mu \mathrm{g} / \mathrm{mL}$ against $S$. aureus. Data at $10 \mu \mathrm{g} / \mathrm{mL}$ was typical of results for all concentrations (Figure 2A-B). Chitosan of high molecular weight had greater effect against the grampositive bacteria $P$. acnes and $S$. aureus, with molecular weight having a more pronounced impact against $S$. aureus.

\section{Chitosan antibacterial activity is $\mathrm{pH}$ dependent}

Chitosan was tested against $P$. acnes and $S$. aureus at various $\mathrm{pH}$ levels (Figure $2 \mathrm{C}-\mathrm{D}$ ). For $P$. acnes, which did
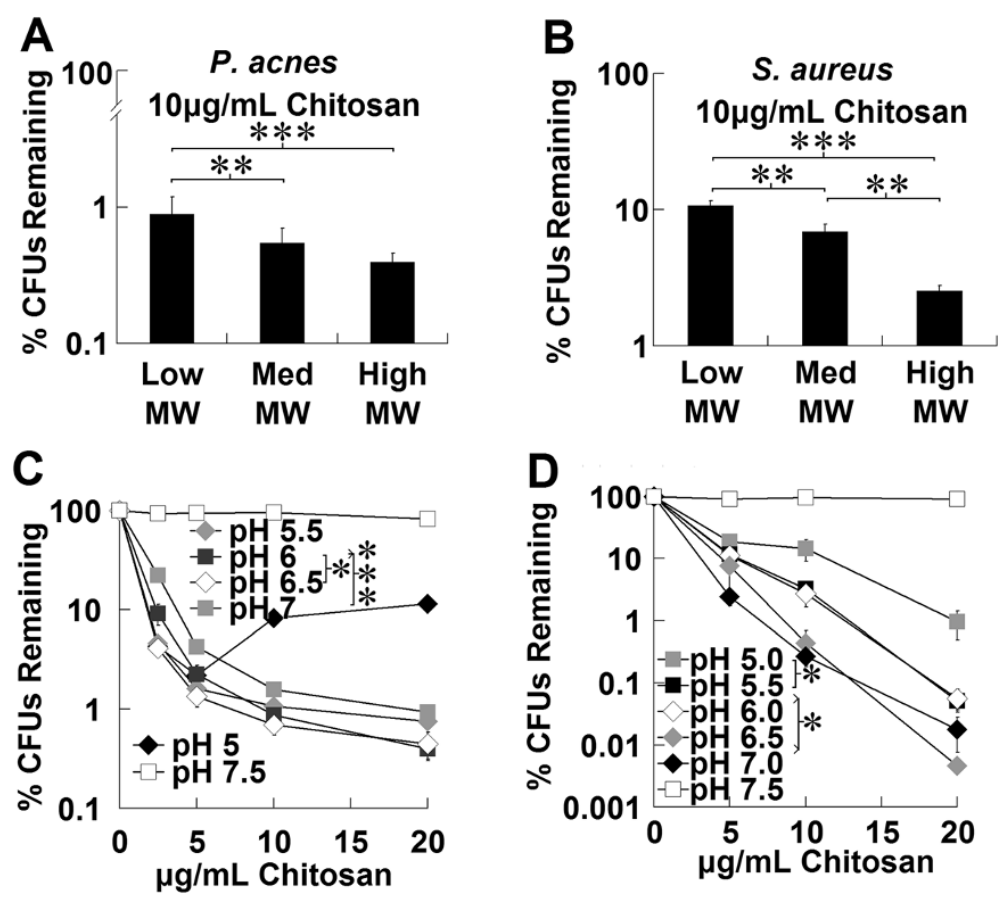

Figure 2 Molecular weight and pH affect chitosan antibacterial activity. (A, B) Chitosan of low (50-190 kD), medium (190-310 kDa), or high (310-375+ kDa) molecular weight or (C, D) chitosan at different pH was incubated with (A, C) P. acnes or (B, D) S. aureus for 3 hours to assess antibacterial activity. Bacteria was then enumerated by colony-forming unit assay to determine concentration, which was plotted as a percentage of untreated sample. Error bars represent SEM ( $n=3$ for A, C, D, $n=4$ for $\mathbf{B}$, independent experiments). ${ }^{*} p<0.05$, ${ }^{* *} p<0.01$, and ${ }^{* * *} p<0.001$ (sign test across all concentrations for $\mathbf{A}, \mathbf{C}, \mathbf{D}$, paired t-test for $\mathbf{B}$ ). 
not multiply during the experiment, chitosan was observed to be more effective at lower $\mathrm{pHs}$, with $\mathrm{pH}$ 5.56.5 having indistinguishable activity. An anomalous hook effect was apparent in all trials at $\mathrm{pH}$. Low $\mathrm{pH}$ had an antibacterial effect, but this was small compared to the effect of chitosan. Chitosan's positively charged amine group has a $\mathrm{pK}_{\mathrm{a}}$ of approximately 6.3, and thus, its solubility falls rapidly in this $\mathrm{pH}$ region. The stock chitosan solutions used had partially precipitated at $\mathrm{pH} 7$, and fully precipitated at $\mathrm{pH} 7.5$, when the amine group has minimal positive charge. We observed chitosan to be almost completely ineffective at $\mathrm{pH}$ 7.5. For S. aureus at lower pHs, however, we saw chitosan effectiveness generally decline with reduction in $\mathrm{pH}$, which was correlated with a reduction in the bacterial growth rate for the duration of the experiment, as determined by untreated controls.

\section{Electron microscopy shows chitosan alters cell surface of P. acnes}

Chitosan is thought to exert its antibacterial activity by disturbing the integrity of the cell membrane. To determine if a similar mechanism is employed in the killing of $P$. acnes, we examined chitosan-treated bacteria using transmission electron microscopy. Micrographs of untreated $P$. acnes illustrate the bacterium's normal surface architecture, which appears smooth and sharply layered (Figure 3A-B). In contrast, the chitosan-treated bacteria lost the integrity of their surface structure, which appears disturbed, losing its crisp, well-defined structure (Figure 3C-D). Chitosan bound to the outside of the cell wall is readily apparent. In addition, we observed the $P$. acnes membrane to be shrunken, and out of contact with the cell wall in places. These images reveal that chitosan perturbs the surface integrity of $P$. acnes, which could account for its antimicrobial activity.

\section{Fluorescence confocal microscopy shows chitosan-bacteria interaction}

Cyanoditolyl Tetrazolium Chloride (CTC)-stained $P$. acnes was treated with Fluorescein Isothiocyanate (FITC)-labeled chitosan and examined via fluorescence microscopy. Untreated bacteria were distributed evenly in solution (Figure 4A). However, when treated with chitosan, bacteria were clustered into small chitosan particles (Figure 4B) often visible to the naked eye. Chitosan
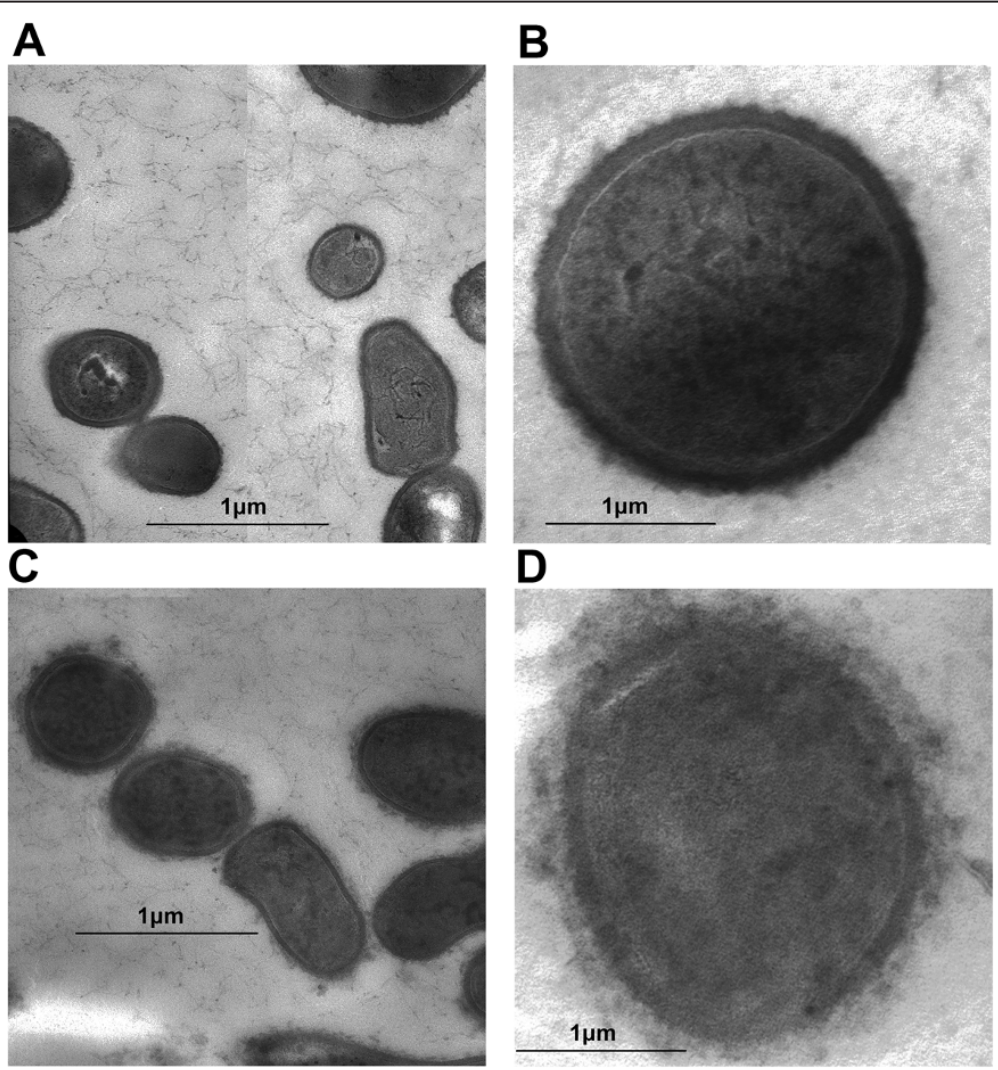

Figure 3 Electron microscopy shows antibacterial effect. P. acnes bacteria were (A, B) left untreated or (C, D) incubated for one hour with chitosan, and then prepared for electron microscopy. Images were taken at 19,000x magnification with 1 um scale bar (A, C) or 72,000x magnification with $250 \mathrm{~nm}$ scale bar (B, D). Figure 4A was modified by moving two parts of a larger image together. Images are representative of two separate experiments. 

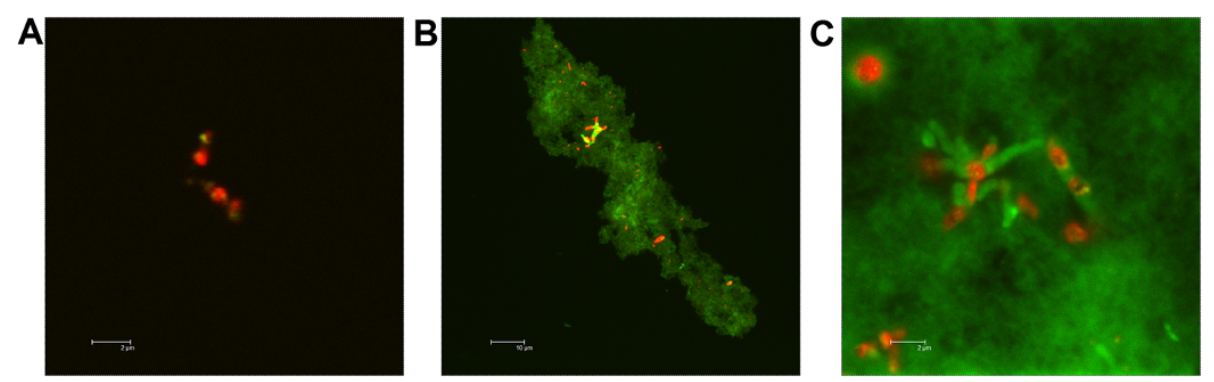

Figure 4 Fluorescence confocal microscopy shows chitosan-bacteria interaction. CTC-stained $P$. acnes bacteria were (A) left untreated or (B, C) incubated for one hour with FITC-labeled chitosan, and then examined by fluorescence microscopy. Scale bar is $2 \mu \mathrm{m}$ (A, C) or $10 \mu \mathrm{m}$ (B). Bacteria is red, while chitosan is green.

particles ranged in size from $5-200 \mu \mathrm{m}$, and contained 0-50 individual bacteria. All observed bacteria were bound to these particles. Furthermore, within the particles of chitosan, P. acnes bacteria were often found in areas of particularly high chitosan concentration (Figure 4C). The chitosan appears directly attached to the surface of the bacteria, where it likely exerts its antimicrobial action.

\section{Clinical isolates of $P$. acnes are sensitive to chitosan}

To determine potential antimicrobial activity in clinical settings, we tested chitosan against $P$. acnes isolates from 8 different acne patients (Figure 5). All showed similar vulnerability to chitosan. One strain, B63.1, demonstrated somewhat more resistance compared to

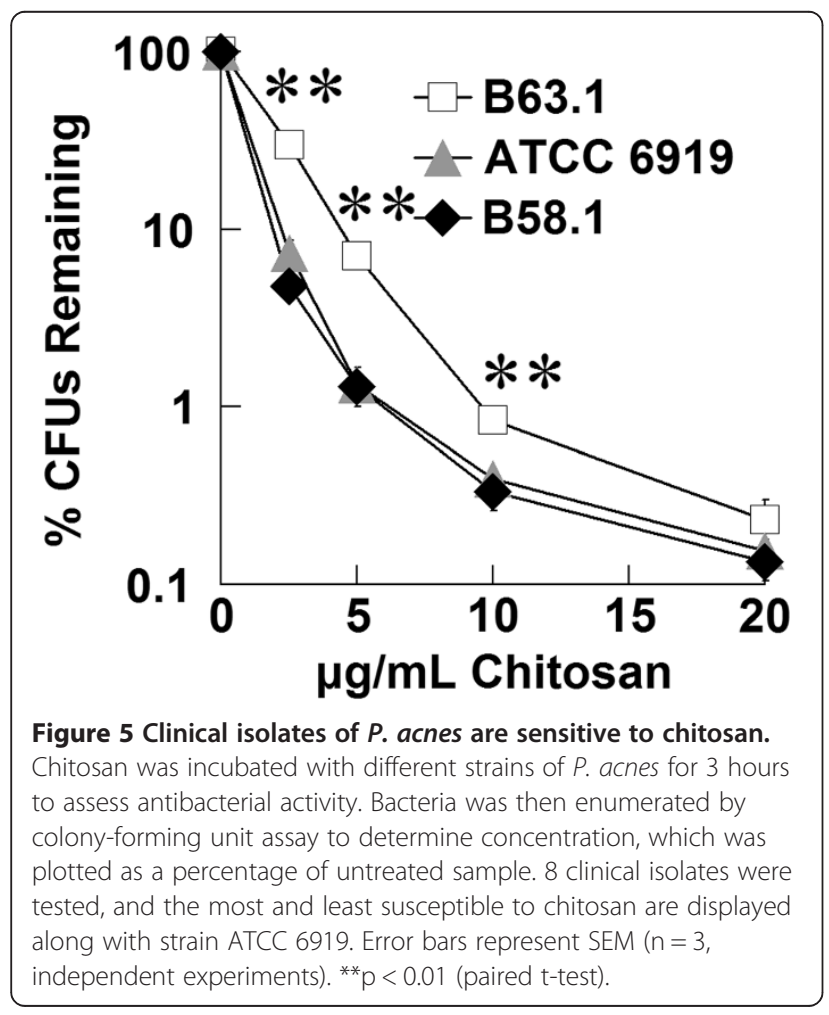

P. acnes ATCC strain 6919 at 5 and $10 \mu \mathrm{g} / \mathrm{mL}$ chitosan, but at $20 \mu \mathrm{g} / \mathrm{mL}$, all strains were reduced by nearly 3 logs.

Chitosan and benzoyl peroxide have additive antibacterial activity in combination

Benzoyl peroxide (BP), a common treatment for acne vulgaris, was tested in combination with chitosan against $P$. acnes (Figure 6). Amine groups, particular tertiary amines, are thought to catalyze the antimicrobial mechanism of benzoyl peroxide (Burkhart and Burkhart 2007), and chitosan has a primary amine group. We found that BP at $2 \mu \mathrm{g} / \mathrm{mL}$ inhibited $P$. acnes growth by a half $\log$.

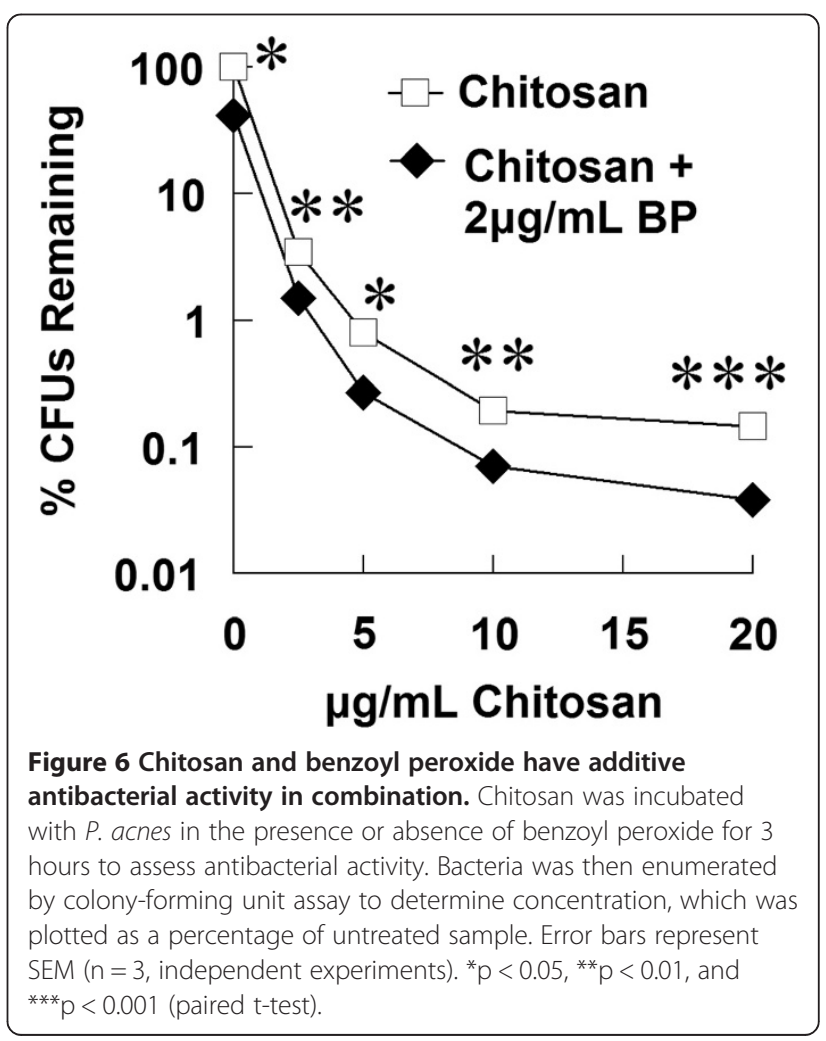


Together, BP and chitosan had additive but not synergistic antimicrobial activity against $P$. acnes.

\section{Chitosan is less toxic to human cells than benzoyl peroxide}

One major adverse effect of benzoyl peroxide as a treatment for acne vulgaris is its high toxicity to human cells. Clinically, BP leads to irritation, especially at a higher concentrations, decreasing patient compliance. We compared the cytotoxicity of chitosan with BP using a 3-(4,5-dimethylthiazol-2-yl)-5-(3-carboxymethoxyphenyl)-2-(4-sulfophenyl)-2H-tetrazolium (MTS) assay. We found that that chitosan is significantly less toxic to keratinocytes and primary human monocytes than benzoyl peroxide (Figure 7). Furthermore, BP concentrations of $20-40 \mu \mathrm{g} / \mathrm{mL}$ results in nearly $100 \%$ cell death, but many cells survive when exposed to similar concentrations of chitosan.

\section{Discussion}

As bacteria develop resistance to common antibiotic therapies, there is a need to develop new treatment options. This public health issue is clearly evident in acne vulgaris, which affects over $80 \%$ of the population at some point in their lives. Therefore, we assessed the potential of chitosan as an antimicrobial agent against two common cutaneous pathogens. In addition, we gathered data on the antibacterial mechanism of chitosan, and determined how certain properties of chitosan affect its antibacterial activity.

Chitosan appears to only be effective against bacteria when dissolved. Due to its pKa of $\sim 6.3$, chitosan is only weakly soluble at neutral $\mathrm{pH}$. We found that chitosan had little antimicrobial activity above $\mathrm{pH} 7$, so it was necessary to keep chitosan at sufficiently low $\mathrm{pH}$ to enhance its antimicrobial effect. It is anticipated that chitosan is most effective at lower $\mathrm{pH}$ when more of the amine groups are positively charged. Chitosan could then bind to negatively charged bacterial surface, facilitating its antibacterial activity.

By comparing two very different cutaneous pathogens, we found other factors affect chitosan's antimicrobial effectiveness. S. aureus multiplied more quickly when closest to $\mathrm{pH} 7$ in our experiments. At the same time, we measured increased chitosan effect against these more rapidly growing bacteria, as long as the chitosan remained at least partially dissolved. P. acnes did not multiply during chitosan treatment, and we found little effect of $\mathrm{pH}$ on antimicrobial activity for dissolved chitosan. Additionally, chitosan activity was significantly reduced against both bacterial species in buffers that did not include $0.03 \%$ Trypticase Soy Media or other nutrients, despite the fact that this media completely precipitates and inactivates chitosan at higher concentrations. This could potentially be due to a change in bacterial surface characteristics in response to an environment devoid of nutrients, hastening transition to a static growth phase. Moreover, we observed reduced effectiveness of chitosan with increasing $\mathrm{NaCl}$ concentration, which also slowed S. aureus growth (unpublished data).

Bacterial surface characteristics may account for chitosan's improved antimicrobial activity against rapidly growing bacteria at higher pHs. One study correlated surface hydrophobicity with chitosan binding (Chung and $\mathrm{Su}, 2004)$. Escherichia coli in the exponential phase of growth have greater negative surface charge and decreased hydrophobicity (Walker et al. 2005), and other species of bacteria may follow this pattern. This would allow chitosan to have higher affinity for bacteria in the exponential phase, and thus, greater activity against them. However, one study found surface charge and hydrophobicity largely unchanged between the midexponential and stationary phases in S. aureus (Beck et al. 1988), while another found variable increase or decrease in hydrophobicity between the mid-exponential and stationary phases depending on strain (Baselga et al.
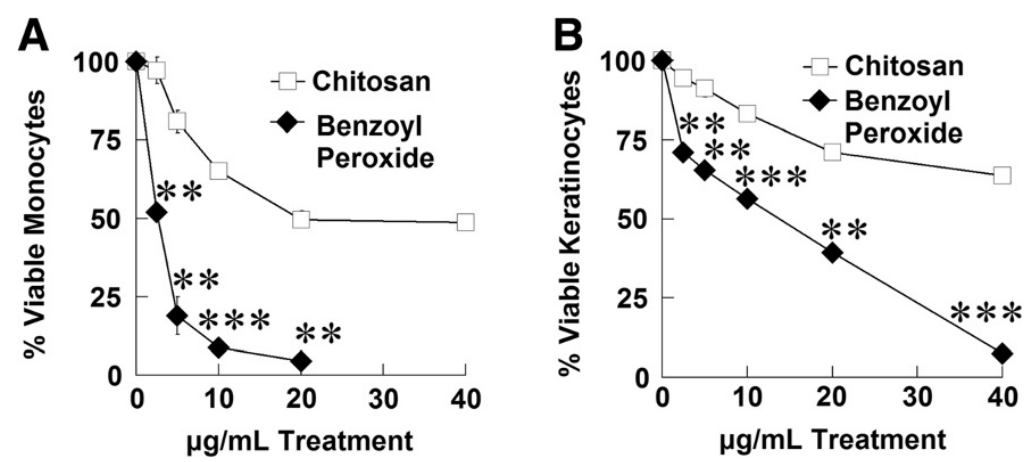

Figure $\mathbf{7}$ Chitosan is less toxic to human cells than benzoyl peroxide. Human monocytes (A) or keratinocytes (B) were incubated with chitosan or benzoyl peroxide for 16 hours. Cell viability was then determined by MTS assay. Error bars represent SEM ( $n=3$, independent experiments for $\mathbf{A}$, one experiment for $\mathbf{B}$ ). ${ }^{* *} \mathrm{p}<0.01$, and ${ }^{* * *} \mathrm{p}<0.001$ (t-test). 
1992). Therefore, other factors may be involved, such as increased protonation of surface proteins reducing chitosan binding at low $\mathrm{pH}$.

Our electron microscopy examination $P$, acnes under chitosan treatment was similar to previous results on gram-positive bacteria (Moon et al. 2007; Raafat et al. 2008; Eaton et al. 2008; Fernandes et al. 2009). We saw that chitosan adheres to the surface of the bacteria cell wall, a conclusion supported by our fluorescence microscopy study. Additionally, the osmotic pressure-induced disruption and shrinkage of the bacterial membrane was consistent with a proposed antibacterial mechanism involving a reduction in the permeability of the membrane to intracellular components (Young et al. 1982). Indeed, other studies have shown potassium leakage (Raafat et al. 2008) as well as protein and nucleotide leakage (Chung and Chen 2008) in chitosan-treated bacteria. This mechanism is bactericidal, as opposed to the bacteriostatic mechanism of several common antibiotics used to treat acne, possibly giving chitosan treatment an advantage.

Another proposed antibacterial mechanism involves chitosan forming a barrier on the bacterial surface, preventing entrance of nutrients (Zheng and Zhu 2003). Higher molecular weight chitosan would be more effetive in this role, which is consistent with our results and previous results, though only in gram-positive bacteria (Tayel et al. 2010). Also in support of this mechanism, we observed bacteria specimens covered with chitosan via electron microscopy, and bacteria in large aggregates of chitosan via florescence microscopy. It is possible that chitosan operates against bacteria via multiple mechanisms.

None of our 8 clinical isolates demonstrated resistance to chitosan, which has a physical attack mechanism, rather than affecting the bacterial machinery like conventional antibiotics. Because of this, any developed resistance to chitosan would most likely be nonspecific, such as a reduction in surface charge or increase in surface hydrophobicity. These changes may reduce bacterial virulence. Additionally, we have shown that chitosan can be combined with benzoyl peroxide, which is capable of destroying drug-resistant bacteria, but irritating. A combined treatment could avoid side effects associated with highly concentrated benzoyl peroxide, as has been done previously with other drugs (Zeichner 2012; Taylor and Shalita 2004).

Major symptoms of acne vulgaris include inflammation and irritation. To counter these effects, a treatment for acne vulgaris should be anti-inflammatory. Our preliminary data suggests that in vitro, chitosan does not reduce induction of inflammatory cytokines in $P$. acnesstimulated monocytes (unpublished data). We have yet to test the effect of chitosan in other pathways of inflammation involved in the pathogenesis of acne, including the regulation of inflammatory lipids. Indeed, chitosan has been shown to affect lipid binding (Wydro et al. 2007) and is currently used as diet supplement. Furthermore, chitosan has been shown to increase the permeability of epithelial cell junctions (Smith et al 2004). This could allow treatments with chitosan to reach deeper into pilosebaceous follicles or dermal layers. Further studies are warranted to test these properties in acne and other models of skin infection.

Overall, chitosan has been shown to be effective against $P$. acnes and $S$. aureus under specific conditions in vitro. To be effective clinically, chitosan activity in biological environments must be studied. Indeed chemical modification of chitosan has shown some promising data (Chen and Chou 2005; Mohy Eldin et al. 2008; Ji et al. 2009). Nevertheless, this is the first study to demonstrate that chitosan has several properties that make it a very promising choice for effective treatment of $P$. acnes infection. Future studies are needed to develop an effective way to use chitosan in vivo.

\section{Competing interests}

The authors declare that they have no competing interest.

\section{Acknowledgements}

This project was funded by the NIH RO1 grant AR053542. We would like to extend our thanks to Marianne Cilluffo for assistance with electron microscopy and Matt Schibler for assistance with fluorescence microscopy.

\section{Author details}

'Division of Dermatology, David Geffen School of Medicine at UCLA, Los Angeles, CA 90095, USA. ²Division of Immunology, Beckman Research Institute, City of Hope National Medical Center, 1500 E. Duarte Road, Duarte, CA 91010, USA. ${ }^{3}$ Department of Dermatology, Greater Los Angeles Healthcare System Veterans Affairs, Los Angeles, CA 90073, USA.

Received: 28 June 2013 Accepted: 2 July 2013

Published: 6 July 2013

\section{References}

Baselga R, Albizu I, Penedes JR, Aguilar B, Iturralde M, Amorena B (1992) Hydrophobicity of Ruminant Mastitis Staphylococcus aureus in Relation to Bacterial Aging and Slime Production. Curr Microbiol 25:173-179

Beck G, Puchelle E, Plotkowski C, Peslin R (1988) Effect of growth on surface charge and hydrophobicity of Staphylococcus aureus. Ann Inst Pasteur Microbiol 139:655-664

Bellew S, Thiboutot D, Del-Rosso JQ (2011) Pathogenesis of acne vulgaris: what's new, what's interesting and what may be clinically relevant. J Drugs Dermatol 10:582-585

Brown MA, Daya MR, Worley JA (2009) Experience with Chitosan Dressings in a Civilian EMS System. J Emerg Med 37:1-7

Burkhart CG, Burkhart CN (2007) Treatment of acne vulgaris without antibiotics: tertiary amine-benzoyl peroxide combination vs. benzoyl peroxide alone. Int J Dermatol 46:89-93

Chen YL, Chou CC (2005) Factors affecting the susceptibility of Staphylococcus aureus CCRC 12657 to water soluble lactose chitosan derivative. Food Microbiol 22:29-35

Chen YM, Chung YC, Wang LW, Chen KT, Li SY (2002) Antibacterial Properties of Chitosan in Waterborne Pathogen. J Environ Sci Health A37:1379-1390

Chung YC, Chen CY (2008) Antibacterial characteristics and activity of acidsoluble chitosan. Bioresour Technol 99:2806-2814

Chung YC, Su YP, Chen CC, Jia G, Wang HL, Wu JCG, Lin JG (2004) Relationship between antibacterial activity of chitosan and surface characteristics of cell wall. Acta Pharmacol Sin 25:932-936 
Cory AH, Owen TC, Barltrop JA, Cory JG (1991) Use of an aqueous soluble tetrazolium/formazan assay for cell growth assays in culture. Cancer Commun 3:207-212

Eaton P, Fernandes JC, Pereira E, Pintado ME, Malcata FX (2008) Atomic force microscopy study of the antibacterial effects of chitosans on Escherichia coli and Staphylococcus aureus. Ultramicroscopy 108:1128-1134

Fernandes JC, Eaton P, Gomes AM, Pintado ME, Malcata FX (2009) Study of the antibacterial effects of chitosans on Bacillus cereus (and its spores) by atomic force microscopy imaging and nanoindentation. Ultramicroscopy 109:854860

Jappe U, Heuck D, Strommenger B, Wendt C, Werner G, Altmann D, Witte W (2008) Staphylococcus aureus in Dermatology Outpatients with Special Emphasis on Community-Associated Methicillin-Resistant Strains. J Invest Dermatol 128:2655-2664

Ji QX, Zhong DY, Lu R, Zhang WQ, Deng J, Chen XG (2009) In vitro evaluation of the biomedical properties of chitosan and quaternized chitosan for dental applications. Carbohydr Res 344:1297-1302

Kong M, Chen XG, Xing K, Park HJ (2010) Antimicrobial properties of chitosan and mode of action: A state of the art review. Int J Food Microbiol 144:51-63

Kraft J, Freiman A (2011) Management of acne. Can Med Assoc J 183:E430-E435

Kurita K (2006) Chitin and Chitosan: Functional Biopolymers from Marine Crustaceans. Mar Biotechnol 8:203-226

Kurokawa I, Danby FW, Ju Q, Wang X, Xiang LF, Xia L, Chen W, Nagy I, Picardo M, Suh DH, Ganceviciene R, Schagen S, Tsatsou F, Zouboulis CC (2009) New developments in our understanding of acne pathogenesis and treatment. Exp Dermatol 18:821-832

Lee BC, Kim MS, Choi SH, Kim KY, Kim TS (2009) In vitro and in vivo antimicrobial activity of water-soluble chitosan oligosaccharides against Vibrio vulnificus. Int J Mol Med 24:327-333

Mohy Eldin MS, Soliman EA, Hashem Al, Tamer TM (2008) Antibacterial Activity of Chitosan Chemically Modified with New Technique. Trends Biomater Artif Organs 22:125-137

Moon JS, Kim HK, Koo HC, Joo YS, Nam HM, Park YH, Kang MI (2007) The antibacterial and immunostimulative effect of chitosan oligosaccharides against infection by Staphylococcus aureus isolated from bovine mastitis. Appl Microbiol Biotechnol 75:989-998

No HK, Meyers SP, Prinyawiwatkul W, Xu Z (2007) Applications of Chitosan for Improvement of Quality and Shelf Life of Foods: A Review. J Food Sci 72: R87-R100

Patel M, Bowe WP, Heughebaert C, Shalita AR (2010) The development of antimicrobial resistance due to the antibiotic treatment of acne vulgaris: a review. J Drugs Dermatol 9:655-664

Qaqish RB, Amiji MM (1999) Synthesis of a fluorescent chitosan derivative and its application for the study of chitosan-mucin interactions. Carbohydr Polym 38:99-107

Raafat D, Bargen K, Hass A, Sahl HG (2008) Insights into the Mode of Action of Chitosan as an Antimicrobial Compound. Appl Environ Microbiol 74:37643773

Rabea El, Badawy MET, Stevens CV, Smagghe G, Steurbaut W (2003) Chitosan as Antimicrobial Agent: Applications and Mode of Action. Biomacromolecules 4:1457-1465

Singla AK, Chawla M (2001) Chitosan: some pharmaceutical and biological aspects - an update. J Pharm Pharmacol 53:1047-1067

Smith K, Wood E, Dornish M, et al. (2004) Effect of Chitosan on Epithelial Cell Tight Junctions. Pharm Res 21:43-49

Song M, Seo SH, Ko HC, Oh CK, Kwon KS, Chang CL, Kim MB (2011) Antibiotic susceptibility of Propionibacterium acnes isolated from acne vulgaris in Korea. J Dermatol 38:667-673

Taylor GA, Shalita AR (2004) Benzoyl peroxide-based combination therapies for acne vulgaris: a comparative review. Am J Clin Dermatol 5:261-265

Tayel AA, Moussa S, Opwis K, Knittel D, Schollmeyer E, Nickisch-Hartfiel A (2010) Inhibition of microbial pathogens by fungal chitosan. Int J Biol Macromol 47:10-14

Walker SL, Hill JE, Redman JA, Elimelech M (2005) Influence of Growth Phase on Adhesion Kinetics of Escherichia coli D21g. Appl Environ Microbiol 71:30933099

Wydro P, Krajewska B, Hac-Wydro K (2007) Chitosan as a lipid binder: a langmuir monolayer study of chitosan-lipid interactions. Biomacromolecules 8:26112617
Young DH, Kohle H, Kauss H (1982) Effect of Chitosan on Membrane Permeability of Suspension-Cultured Glycine max and Phaseolus vulgaris Cells. Plant Physiol 70:1449-1454

Zeichner JA (2012) Optimizing topical combination therapy for the treatment of acne vulgaris. J Drugs Dermatol 11:313-317

Zheng LY, Zhu JF (2003) Study on antimicrobial activity of chitosan with different molecular weights. Carbohydr Polym 54:527-530

doi:10.1186/2191-0855-3-37

Cite this article as: Champer et al:: Chitosan against cutaneous

pathogens. AMB Express 2013 3:37.

\section{Submit your manuscript to a SpringerOpen ${ }^{\circ}$ journal and benefit from:}

- Convenient online submission

- Rigorous peer review

- Immediate publication on acceptance

- Open access: articles freely available online

- High visibility within the field

- Retaining the copyright to your article

Submit your next manuscript at $>$ springeropen.com 